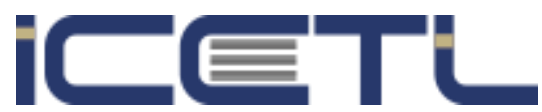

International Conference on Research in Education, Teaching and Learning

Paris, France| November 2-4, 2018

\title{
Measuring of the ICT Literacy Level of the entering Students in the Mexican and Slovakian Higher Education
}

\author{
G. Kiss ${ }^{1}$, C. A. T. Gastelu ${ }^{2}$ \\ ${ }^{1}$ Department of Mathematics and Informatics, J. Selye University, Komarno, Slovakia \\ ${ }^{2}$ Facultad de Administración, Universidad Veracruzana, Veracruz, Mexico
}

\begin{abstract}
The students generally use technology for communication in the European Union and outside of the Union. We have to see in this research the ICT knowledge level of the students in the higher education to make decision about the application and retraining methods. It is important to know can we find any difference in ICT literacy between the Slovakian and the Mexican entering students to see how long is the way to finish the ICT revolution in these countries. We measured the ICT literacy level with a tool consisting of 15 items (Likert scaled). The data analysis was performed with SPSS software using descriptive statistics and Mann-Whitney test. We have made more analysis by gender by countries. We have found significant differences by countries. After the analyzing process we can say the subjective ICT literacy level of Mexican students by every item is higher than Slovakian students. We have found more items where was not difference in the subjective ICT literacy level by boys in Slovakia it means the gender-gap is not so big in this country.
\end{abstract}

\section{Introduction}

Communication and technology have an important role in life and especially in education. Nowadays, students generally use technology for communication. When using technology in education, there may be some communication barriers.

An international comparison analysis tool is an effective way for understanding the situation between two or more different regions of the world. In this sense, literature shows the relevance of analyzing how ICT has been used in education to better understand educational strategies, learning methods and pedagogical techniques in order to effectively apply ICT in the classroom.

The purpose of this study is to identify the levels of ICT Competencies of students from two countries, one in Slovakia (in the EU Commission) and the other in Mexico (out of EU Commission). First of all we have to see the ICT knowledge level of the students to make decision about the application and retraining methods.

It is important to know can we find any difference in ICT literacy between the Slovakian and the Mexican entering students in the higher education to see how long is the way to finish the ICT revolution in these countries. On the other hand is it important to see which topic need more attention from the teachers in the high school to give a good knowledge for the student before they go in the higher education.

Some earlier research analyzed the ICT literacy of the students in Hungary on different levels [1], [2], [3], [4]. The current research analyses the ICT literacy level of the Mexican and Slovakian students in Higher Education. 


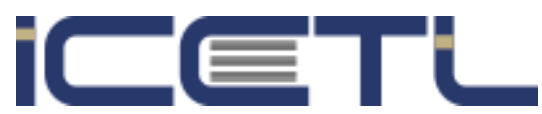

International Conference on Research in Education, Teaching and Learning

Paris, France| November 2-4, 2018

\section{Information technology education in Slovakia}

The education of Informatics from the 2 nd grade has been compulsory since the school year of 2008/2009, since the introduction of the school reform but it also appears in the 1st grade as well as in the nursery school curriculum though not as a compulsory subject. It is compulsory to have 1 Informatics lesson a week in the junior section and 0.5 lesson a week in the senior section that can be raised by the schools' own programme. Some schools took the opportunity and increased it to 1 lesson a week. The National Educational Programme does not assign precisely what teachers have to teach in the various grades but announces the school leaving standards to reach at the end of the senior section. So it does not matter if programming is taught in the 6th grade in one school and in the 8th grade in another school; the aim is to reach the school leaving standards. It is part of the educational programme of the school how its students should reach these standards, how many lessons they have a week and at what pace they learn the material; this programme is accepted by the management of the school and its teachers together .

The National Educational Programme divides Informatics into 5 topics (it does not specify the number of lessons):

1. Information around us

2. Communication with the help of the means of the ICT

3. Problem solving, thinking with the help of algorithms

4. Basic principles of the operation of the ICT tools

5. IS society

These 5 topics are then to be divided into the school leaving standards.

\section{Information technology education in Mexico}

The primary education is six years in length and runs from grade one through grade six and the content based on the national curriculum while the National Institute for Assessment of Education but not include Information Technology as subject in education.

The lower secondary education is three years in length and runs from grade seven through grade nine. The students follow either an academic track or a technical track but not include Information Technology as subject in education.

Upper secondary education is a further three years in length, after three years of lower secondary, and runs from grade 10 to grade 12 and it is the first level where ICT appear in official education form. In the general secondary school are 6 hours per month for Computer Science on the academic track and 3 hours per month for ICT on technical track.

\section{Analyzing the entering students' ICT literacy level}

The purpose of this study is to compare the ICT literacy level of students from Slovakian and Mexican universities. 


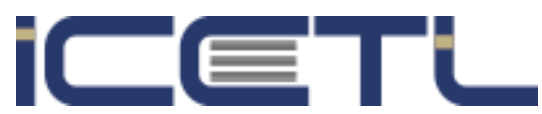

International Conference on Research in Education, Teaching and Learning

Paris, France| November 2-4, 2018

The number of participants: The sample consisted of 440 students, 226 Serbian and 214 Slovakian students (Table 1.).

Table 1. The number of participants by gender and country

\begin{tabular}{|c|c|c|c|}
\hline & Male & Female & Total \\
\hline Mexican & 151 & 151 & 302 \\
\hline Slovakian & 107 & 107 & 214 \\
\hline Total & 258 & 258 & 516 \\
\hline
\end{tabular}

The students filled out a self-reported questionnaire with 15 items. We have used Likert-type rating scales to measure the ICT literacy level of students [5].

Liker scales are commonly used by self-reported questionnaire, providing a range of responses to a given question or statement [6]. There were 4 categories of response: 1 = basic level; 2 = medium; 3 = advanced, 4 = „,master”.

The reliability of the questionnaire obtained by the technique of Cronbach- $\alpha$ was 0.920 it means the reliability of the questionnaire is very good.

\section{The results of Independent Samples Mann-Whitney U test}

The Likert scale is ordinary scale, and as such we can calculate mean, min, max, median, modus, std. dev. etc. We can use the nonparametic tests where we need ordinary variables. We have two independent samples so we could use the MannWhitney-Wilcoxon test for 2 samples [7]. The Mann-Whitney-Wilcoxon test seems better choice versus $t$ test by Likert-type data [8], because it is testing the medians of the samples.

We used the Mann-Whitney independent sample U test of SPSS to compare the means of scores taken by the students. Monitoring was held on $\mathrm{p}=5 \%$ significancy level in the whole analyzing process.

We used 3 different ways of comparison: by countries, by gender and by gender in Slovakia or in Serbia

\subsection{The results of Independent Samples Mann-Whitney $U$ test by countries}

If we summarize the scores of all items and make the comparison can we see the ICT literacy level of students by countries. The result of Mann-Whitney U test on the total scores has shown significant difference between the 2 group of students by ICT literacy, $\mathrm{p}=0.000$. 
Table 2. The results of Independent Samples Mann-Whitney U test by countries

\begin{tabular}{|c|c|c|c|c|}
\hline Number of item & Item & $\begin{array}{c}\text { Serbian } \\
\text { (Mean score) } \\
\end{array}$ & $\begin{array}{c}\text { Slovakian } \\
\text { (Mean score) }\end{array}$ & $\mathrm{p}$ \\
\hline 1 & Handling Operating System (OS) & 2,61 & 2,10 & 0,00 \\
\hline 2 & Word processor & 2,76 & 2,36 & 0,00 \\
\hline 3 & Spreadsheet & 2,5 & 1,93 & 0,00 \\
\hline 4 & Database Management & 2,33 & 1,56 & 0,00 \\
\hline 5 & Multimedia & 2,53 & 2,06 & 0,00 \\
\hline 6 & Software specific to my degree & 2,17 & 1,71 & 0,00 \\
\hline 7 & Using documentary bases (Such as EBSCO) & 2,31 & 1,57 & 0,00 \\
\hline 8 & Web Browsing & 3,01 & 2,80 & 0,01 \\
\hline 9 & Internet Communication & 2,9 & 2,77 & 0,04 \\
\hline 10 & Internet Safety & 2,52 & 2,05 & 0,00 \\
\hline 11 & Website design & 2,3 & 1,38 & 0,00 \\
\hline 12 & Using learning platforms & 2,22 & 1,28 & 0,00 \\
\hline 13 & Image Editing & 2,4 & 2,06 & 0,00 \\
\hline 14 & Video Editing & 2,21 & 1,61 & 0,00 \\
\hline 15 & Creating simulations and animations & 2,31 & 1,31 & 0,00 \\
\hline
\end{tabular}

We calculated the mean scores by items and also calculated the difference between them grouped by countries. Then we can made analysis process with Mann-Whitney U test (Table 2.).

According to the table we can see the scores of the students from different countries; we can see that the subjective ICT literacy level of Mexican students is significant higher than the Slovakian students by every items. It means the Mexican students can take the advantages of the higher number of ICT lessons.

\subsection{The results of Independent Samples Mann-Whitney $U$ test by gender}

We have seen the Mexican students reached significant higher scores by every items. It is important to see, the difference is same by the genders too, or not. We calculated the mean scores by items and also calculated the difference between them grouped by genders. Then can we make analysis process with Mann-Whitney $\mathrm{U}$ test by boys (Table 3.) and girls (Table 4.). 


\section{iᄃ医TL}

International Conference on Research in Education, Teaching and Learning

Paris, France| November 2-4, 2018

Table 3. The results of Independent Samples Mann-Whitney U test by countries by boys

\begin{tabular}{|c|c|c|c|c|}
\hline Number of item & Item & $\begin{array}{c}\text { Mexican boys } \\
\text { (Mean score) }\end{array}$ & $\begin{array}{c}\text { Slovakian boys } \\
\text { (Mean score) }\end{array}$ & $\mathrm{p}$ \\
\hline 1 & Handling Operating System (OS) & 2,52 & 2,19 & $\mathbf{0 , 5 6}$ \\
\hline 2 & Word processor & 2,71 & 107 & 0,09 \\
\hline 3 & Spreadsheet & 2,48 & 0,881 & 0,00 \\
\hline 4 & Database Management & 2,37 & 2,3 & 0,00 \\
\hline 5 & Multimedia & 2,48 & 258 & $\mathbf{0 , 0 6}$ \\
\hline 6 & Software specific to my degree & 2,16 & 0,889 & 0,00 \\
\hline 7 & Using documentary bases (Such as EBSCO) & 2,36 & 0 & 0,00 \\
\hline 8 & Web Browsing & 2,99 & 0 & $\mathbf{0 , 5 8}$ \\
\hline 9 & Internet Communication & 2,83 & 2,19 & $\mathbf{0 , 8 4}$ \\
\hline 10 & Internet Safety & 2,47 & 107 & 0,02 \\
\hline 11 & Website design & 2,31 & 0,881 & 0,00 \\
\hline 12 & Using learning platforms & 2,21 & 2,3 & 0,00 \\
\hline 13 & Image Editing & 2,38 & 258 & 0,04 \\
\hline 14 & Video Editing & 2,19 & 0,889 & 0,00 \\
\hline 15 & Creating simulations and animations & 2,27 & 0 & 0,00 \\
\hline
\end{tabular}

According to the table (Table 3.) we can find any significant differences in the subjective ICT literacy level of Mexican and Slovakian boys. It means the Mexican and Slovakian boys do not have same subjective ICT literacy level in the higher education, by the big part of items the scores of Mexican boys are higher. On other hand the subjective ICT literacy level of Mexican boys is same with Slovakian boys by handling "Operating System", "Word processor", "Multimedia", "Web browsing" and "Internet communication". It means the difference between the two countries by every items do not based only on the boys. 
International Conference on Research in Education, Teaching and Learning

Paris, France| November 2-4, 2018

Table 4. The results of Independent Samples Mann-Whitney U test by countries by girls

\begin{tabular}{|c|c|c|c|c|}
\hline Number of item & Item & \begin{tabular}{|l|} 
Mexican girls \\
(Mean score)
\end{tabular} & \begin{tabular}{|l}
$\begin{array}{l}\text { Slovakian girls } \\
\text { (Mean score) }\end{array}$ \\
\end{tabular} & $\mathrm{p}$ \\
\hline 1 & Handling Operating System (OS) & 2,7 & 1,75 & 0,00 \\
\hline 2 & Word processor & 2,81 & 2,21 & 0,00 \\
\hline 3 & Spreadsheet & 2,52 & 1,79 & 0,00 \\
\hline 4 & Database Management & 2,28 & 1,5 & 0,00 \\
\hline 5 & Multimedia & 2,57 & 1,84 & 0,00 \\
\hline 6 & Software specific to my degree & 2,18 & 1,65 & 0,00 \\
\hline 7 & Using documentary bases (Such as EBSCO) & 2,25 & 1,6 & 0,00 \\
\hline 8 & Web Browsing & 3,03 & 2,61 & 0,00 \\
\hline 9 & Internet Communication & 2,97 & 2,64 & 0,00 \\
\hline 10 & Internet Safety & 2,56 & 1,88 & 0,00 \\
\hline 11 & Website design & 2,3 & 1,23 & 0,00 \\
\hline 12 & Using learning platforms & 2,23 & 1,26 & 0,00 \\
\hline 13 & Image Editing & 2,42 & 1,93 & 0,00 \\
\hline 14 & Video Editing & 2,23 & 1,47 & 0,00 \\
\hline 15 & Creating simulations and animations & 2,36 & 1,3 & 0,00 \\
\hline
\end{tabular}

According to the table (Table 4.) we can find significant differences by every items as at the comparison by countries. The subjective ICT literacy level of Mexican girls is higher as the Slovakian girls.

It seems the higher number of ICT lessons have more influence by the girls on the ICT literacy level.

\section{Conclusion}

In this research we have tried to analyze the subjective ICT literacy level of the Mexican and Slovakian entering students in the higher education. We have used a selcf-reported questionnaire with 15 items) and Likert-type rating.

After the analyzing process we can say the subjective ICT literacy level of Mexican entering students by every items is higher than Slovakian students.

We have made more analysis by gender by countries. In the following we share the important information connection with it.

We have found significant differences by girls in same case then by countries. It means the subjective ICT literacy level of Mexican girls is higher as the Slovakian 


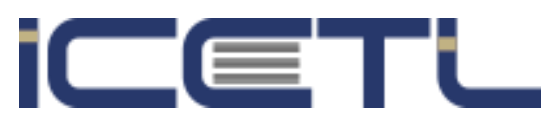

International Conference on Research in Education, Teaching and Learning

Paris, France| November 2-4, 2018

girls. The results by boys are not so clear because Mexican boys have same level with Slovakian boys by handling "Operating System", "Word processor", "Multimedia", "Web browsing" and "Internet communication".

It shows the Mexican girls can take better the advantage of the higher ICT lessons from the primary school to the final exam than the Mexican boys.

\section{References}

1. Kiss G.: 'The survey measuring the informatics skills of the entering Students at Budapest Tech, Bánki Donát Faculty of Mechanical and Safety Engineering', 7th IEEE International Symposium on Intelligent System and Informatics, Subotica, Serbia, 2009, ISBN: 978-1-4244-5348-1, pp:395-397, IEEE Xplore digital library Digital Object Identifier: 10.1109/SISY.2009.5291125

2. Kiss G.: 'A comparison of informatics skills by genders of Hungarian grammar school students', 8th International Conference on Applied Informatics, Eger, 2010, ISBN 978 989472 3, Vol. 2., pp. 17-27

3. Kiss G.: 'A Comparison of Informatics Skills by schooltypes in the 9-10th grades in Hungary', International Journal of Advanced Research in Computer Science, 2011, Vol.: 2, No. 2, ISSN: 0976-5697, pp. 417-428

4. Kiss G.: 'Measuring Student's Computer Science Knowledge at the End of the primary stage in Hungary', 9th IEEE International Symposium on Applied Machine Intelligence and Informatics, Smolenice, Slovakia, 2011, ISBN: 978-1-4244-7428-8, pp. 19-22, IEEE Catalog Number: CFP1108E-CDR, IEEE Xplore digital library Digital Object Identifier: 10.1109/SAMI.2011.5738880;

5. Likert R.: 'A technique for the measurement of attitudes', Archives of Psychology, 1932, Vol.: 27, No.: 140, pp 44-55

6. Jamieson S.: 'Likert scales: how to (ab)use them', Medical Education 2004; Vol.: 38, pp $1217-1218$

11. Boonyasit W.: 'Appropriate statistical analysis for two independent groups of Likert-type data', Dissertation, American University Washington ,2011

12. De Winter J. C. F. and Dodou D.: 'Five-Point Likert Items: $t$ test versus Mann-WhitneyWilcoxon, Practical Assessment', Research \& Evaluation, 2010, Vol.: 15, No.: 11, ISSN: $1531-7714$ 